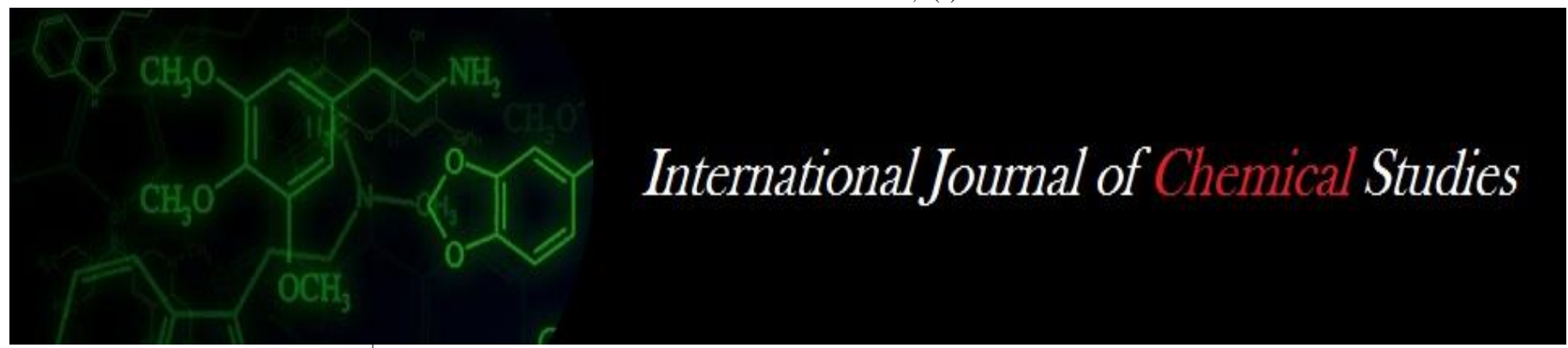

P-ISSN: 2349-8528

E-ISSN: 2321-4902

www.chemijournal.com

IJCS 2020; 8(2): 2760-2763

(C) 2020 IJCS

Received: 15-01-2020

Accepted: 19-02-2020

Indu Ganjeer

Department of Agricultural

Processing and Food

Engineering, Faculty of

Agricultural Engineering, IGKV,

Raipur, Chhattisgarh, India

Yogesh Kumar Chouhan

Department of Agricultural

Processing and Food

Engineering, Faculty of

Agricultural Engineering, IGKV,

Raipur, Chhattisgarh, India

Chandrakali Banjare

Department of Soil and Water

Engineering, Faculty of

Agricultural Engineering, IGKV,

Raipur, Chhattisgarh, India
Corresponding Author:

Yogesh Kumar Chouhan

Department of Agricultural

Processing and Food

Engineering, Faculty of

Agricultural Engineering, IGKV

Raipur, Chhattisgarh, India

\section{Engineering properties of sorghum (Sorghum bicolor L.) and maize (Zea mays L.) grains}

\author{
Indu Ganjeer, Yogesh Kumar Chouhan and Chandrakali Banjare
}

DOI: https://doi.org/10.22271/chemi.2020.v8.i2ap.9169

\begin{abstract}
The engineering properties of sorghum (Sorghum bicolor L.) and maize (Zea mays L.) were determined at moisture content of $11.75 \%$ and $12.52 \%(\mathrm{db})$. The mean values obtained for length, width and thickness were $5.56 \mathrm{~mm}$ and $10.15 \mathrm{~mm}, 5.05 \mathrm{~mm}$ and $8.11 \mathrm{~mm}, 3.56 \mathrm{~mm}$ and $4.22 \mathrm{~mm}$, respectively. The average value for geometric mean diameter, sphericity, bulk density, true density and porosity were 4.64 $\mathrm{mm}$ and $7.03 \mathrm{~mm}, 0.83$ and $0.69,814.62 \mathrm{~kg} / \mathrm{m} 3$ and $726.34 \mathrm{~kg} / \mathrm{m} 3,1455.44 \mathrm{~kg} / \mathrm{m} 3$ and $1211.79 \mathrm{~kg} / \mathrm{m} 3$, $0.44 \%$ and $0.40 \%$ respectively. The angle of repose mean value was $40.50^{\circ}$ and $45.52^{\circ}$. The co-efficient of static friction on three types of structural material were found to be 0.21 and 0.51 (steel), 0.31 and 0.52 (galvanised iron sheet) and 0.26 and 0.4 (wooden).
\end{abstract}

Keywords: Angle of repose, bulk density, groundnut kernels, physical properties, sphericity

\section{Introduction}

Sorghum (Sorghum bicolor L.), a tropical plant belonging to the family of Poaceae, is one of the most important crops in Africa, Asia and Latin America (Anglani, 1998) ${ }^{[1]}$. Sorghum is a major cereal crop, being grown extensively in tropical and subtropical regions of the world. Sorghum is the world fifth most important cereals and widely grown both for food and as a feed grain production. Roughly $90 \%$ of world sorghum area lies in the developing countries. India has the largest share $(32.3 \%)$ of the world's area under sorghum and ranks second in production after the United State. The sorghum grain production of India in 2017-18 was 4.57 Million metric tonnes from an area of 5.10 Million hectares (Anonymous, 2018).

Maize, also known as corn, belongs to the family Poaceae. Maize (Zea mays L.) is one of the most versatile emerging crops having wider adaptability under varied agricultural and climatic conditions. Globally, maize is known as queen of cereals because it has the highest genetic yield potential among the cereals. It is widely cultivated throughout the world and enormous quantity of maize is produced each year than any other grain. The United States produces $40 \%$ of the world's harvest.

The germ constitutes around 3 to 4 per cent of the seed weight (Hoffpauir, 1953). The need for characterization of agricultural and biological material in terms of their physical properties is necessary in the design of system and machine for their post-harvest handling. Thermal conductivity and volumetric specific heat can be used to develop the model for detecting level of insect infestation (Ganjeer et al., 2019) ${ }^{[5]}$. This study discusses the result of such investigation for some relevant physical properties of groundnut for design of groundnut shelling machine. The objective of this study was to determine the following physical properties, linear dimensions, equivalent diameter, sphericity, surface area, volume, density against different materials and angle of repose.

\section{Materials and Methods}

\section{Sorghum and maize grains}

The sorghum and maize were procured from the local market of Durg, Chhattisgarh. After cleaning and grading, the sorghum and maize were stored at room temperature for one month for moisture equilibration. After equilibration, the moisture content of the sorghum and maize were observed to be 12.33 and $11.43 \%$ (d.b.) respectively. 


\section{Moisture content determination}

Moisture content of the sample was determined by using standard hot air electric oven drying method. Around $100 \mathrm{~g}$ unground sample was transferred to a container weight $\left(\mathrm{M}_{1}\right)$, on electronic balance (capacity $500 \mathrm{~g}$, least count $0.001 \mathrm{~g}$ ) and wt. of container + sample $\left(\mathrm{M}_{2}\right)$ to be used. Container containing sample was quickly places in the oven set at $130^{\circ}$ and dried for 6 hours. The drying period was to be considered to begin at the time over attend the required temperature. After this period of 6 hours, container is quickly taken out from oven set and kept into the desiccator having moisture free-silica-gel for cooling to an ambient temperature. When the container was cooled to room or lab temperature, final weight $\left(\mathrm{M}_{3}\right)$ was to be noted down. Moisture content was calculated by following formulae (J.O. Olajide, J.C. Igbeka, 2003) ${ }^{[10]}$.

$\mathrm{M}_{\mathrm{db}}=\left(\mathrm{M}_{2}-\mathrm{M}_{3}\right) /\left(\mathrm{M}_{3}-\mathrm{M}_{1}\right) \times 100$

Where,

$\mathrm{M}_{\mathrm{db}}=$ Moisture content (d.b.) $(\%)$

$\mathrm{M}_{1}=$ Weight of container $(\mathrm{g})$

$\mathrm{M}_{2}=$ Weight of container + sample before drying $(\mathrm{g})$

$\mathrm{M}_{3}=$ Weight of container + sample after drying $(\mathrm{g})$

\section{Determination of physical parameters}

\section{Measurement of length, width and thickness}

The random sample of 30 grains is selected from the given lot. Length, width and thickness of each individual grain is measured with the help of vernier calipers and recorded. The average of each dimension is calculated from individual reading set. The vernier caliper with a least count of $0.01 \mathrm{~cm}$ [Sahay, K.M. and Singh, K.K (1999)] ${ }^{[13]}$.

\section{0 kernel weight}

1000 kernel weight is used in handling and processing of grains. In earlier day's 1000 kernel weight were used in determining the density of kernels. To determine the 1000 kernel weight, one hundred maize kernels were counted manually and then these kernels were weighed by means of an electronic weighing balance with $0.01 \mathrm{~g}$ accuracy and finally extrapolating this mass to 1,000 kernels Sangamithra et al. $(2016)^{[11]}$.

\section{Measurement of diameter}

The diameter of groundnut was measured with the help of vernier calipers having least count $0.01 \mathrm{~cm}$. Sample size was taken as 30 grains at randomly [ Sahay, K.M. and Singh, K.K (1999)] [13]

$\mathrm{D}=(\mathrm{LWT})^{1 / 3}$

Where, D is Diameter of grain $(\mathrm{mm}), \mathrm{L}$ is Length of grain $(\mathrm{mm}), \mathrm{W}$ is Width of grain $(\mathrm{mm})$ and $\mathrm{T}$ is Thickness of grain $(\mathrm{mm})$.

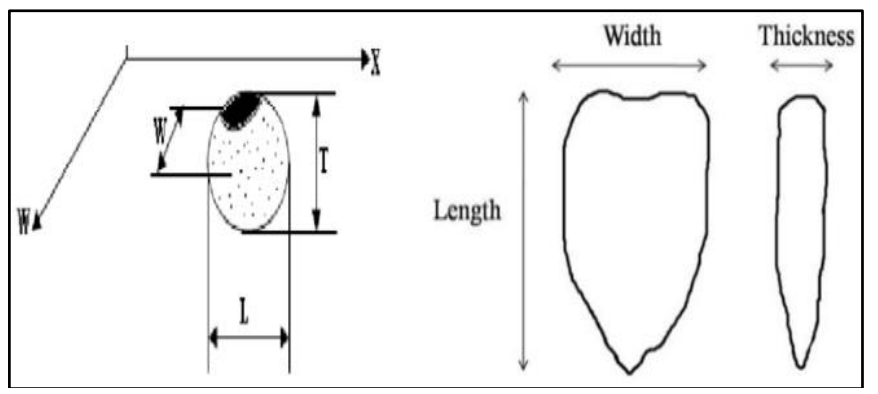

Fig 1: Characteristic dimensions of sorghum and maize grain

\section{Measurement of sphericity}

Sphericity may be defined as the ratio of the diameter of a sphere of the volume as that of the particle and the diameter of the smallest circumscribing sphere or generally the largest diameter of the particle. Sphericity can be expressed as under [Sahay, K.M. and Singh, K.K (1999)] ${ }^{[13]}$.

$\varnothing=\frac{(L W T)}{L}$

Where, $\varnothing$ is Sphericity, L is Length of grain ( $\mathrm{mm}), \mathrm{W}$ is Width of grain $(\mathrm{mm})$ and $\mathrm{T}$ is Thickness of grain $(\mathrm{mm})$.

\section{Determination of Bulk Density}

The bulk density is the mass of group of individual particle divided by the space occupied by entire mass, (Mohsenin, 1980) ${ }^{[9]}$ including the air space. A measuring cylinder (500 $\mathrm{ml}$ ) was filled with seeds to a height of $15 \mathrm{~cm}$ and then the content weighed. The bulk density was calculated as the ratio of the bulk weight and volume of container $(\mathrm{g} / \mathrm{ml})$ [Sebaka, A. and Jideani, V.A. (2008)] ${ }^{[12]}$.

Bulk density $(\mathrm{g} / \mathrm{ml})=$ Bulk weight $(\mathrm{g}) /$ Volume of container (ml)

\section{Determination of True Density}

The true density was determined by using distilled water. In a volumetric cylinder known volume of distilled water was taken. A known weight of seed grains was placed in cylinder. The rise in the volume of distilled water was measured in cylinder. A $250 \mathrm{ml}$ capacity-measuring cylinder was taken; up to $100 \mathrm{ml}$ the cylinder was filled with distilled water. The known weight of seed grains $(20 \mathrm{~g})$ was placed in to the cylinder, and then rise in the volume of distilled water was recorded. By using the following formula, true density was calculated [Sebaka, A. and Jideani, V.A. (2008)] ${ }^{[12]}$.

True density $(\mathrm{g} / \mathrm{ml})=\mathrm{Wt}$. of seed grains $(\mathrm{g}) /$ Rise in volume (ml)

\section{Determination of Porosity}

This is the property of the grain which depends on its bulk and kernel densities. The formula used to calculate the porosity [Sebaka, A. and Jideani, V.A. (2008)] ${ }^{[12]}$.

$\mathrm{P}=\left(1-\rho_{b} / \rho_{t}\right) \times 100$

Where, $\mathrm{P}$ is Porosity, $\rho_{b}$ is bulk density of material $(\mathrm{g} / \mathrm{ml})$ and $\rho_{t}$ is true density of material $(\mathrm{g} / \mathrm{ml})$

\section{Surface area $(\mathbf{S})$}

The surface area (S) were found using the following equations (McCabe et al., 1986; Jain and Bal, 1997; Sangamithra et al. 2016) ${ }^{[8,6,11]}$.

$S=\pi D^{2}$

Where, $\mathrm{S}$ is surface area and $\mathrm{D}$ is geometric mean diameter.

\section{Determination of frictional parameters Determination of angle of repose}

To determine the angle of repose a topless and bottomless cylinder with $11.5 \mathrm{~cm}$ diameter and $13.5 \mathrm{~cm}$ height was used. The cylinder was placed at the center of a cardboard paper and filled with groundnut seed. The cylinder was raised slowly so that a natural heap was formed the angle of repose $(\theta)$ of seeds was calculated from the diameter and height of a 
heap on a cardboard paper [Sebaka, A. and Jideani, V.A. (2008)] ${ }^{[12]}$.

Angle of repose $=\tan ^{-1}(\mathrm{~h} / \mathrm{r})$

Where,

$\mathrm{h}=$ height of heap $(\mathrm{cm})$

$\mathrm{r}=$ radius of heap in base $(\mathrm{cm})$

\section{Co-efficient of friction}

Coefficient of friction was determined against three material surfaces namely steel sheet, wooden and galvanised iron sheet by surface method. The static angle of friction was recorded when the grain just began to slide on the test surface (Mohsenin, 1986) [9]

\section{Results and Discussion}

Length, width, thickness, geometric mean diameter and arithmetic mean diameter of sorghum at moisture content $11.75 \%$ d.b. were $5.56,5.05,3.56 \mathrm{~mm}, 4.64 \mathrm{~mm}$ and $4.72 \mathrm{~mm}$ respectively and sphericity of sorghum at $11.75 \%$ d.b. moisture content is 0.83 which are given in table 1 . Length, width thickness, geometric mean diameter and arithmetic mean diameter of maize at moisture content $12.52 \%$ d.b. were $10.15,8.11,4.22 \mathrm{~mm}, 7.03 \mathrm{~mm}$ and $7.49 \mathrm{~mm}$ respectively and sphericity of maize at $12.52 \%$ d.b. moisture content is 0.69 which is presented in table 2 . The mean geometric diameter could be used to characterize the seed and also important for designing of storage structure.

The bulk density of sorghum and maize were 814.62 and $726.34 \mathrm{~kg} \mathrm{~m}^{-3}$ respectively. The bulk density of sorghum and maize will help in determining the size and capacity of the hopper of a sorghum and maize sheller. The density of sorghum and maize seed is important in estimating the maximum load per unit area that the seed separators of a sorghum amd maize sheller can withstand without sagging. The bulk densities of sorghum and maize are given in table 1 and 2. The true density of sorghum and maize were 1455.44 \& $1211.79 \mathrm{~kg} \mathrm{~m}^{-3}$

The porosity of sorghum is $0.44 \%$ at $11.74 \%$ d.b. moisture content. The porosity of maize is $0.40 \%$ at $12.52 \%$ d.b. moisture content. Porosity depends on the shape, dimensions, and roughness of the grain surface. The porosity of sorghum and maize are given in table 3 . The 1000 kernel weigh and surface area of sorghum and maize are 281.17 and $331.04 \mathrm{~g}$, 67.93 and $155.08 \mathrm{~mm}^{2}$ respectively. Knowledge of surface area of some parts of plant materials like leaf and fruits is important to plant scientist as well as engineers, handling and processing the products. The results are in conformity with the findings of Davies (2009) ${ }^{[2]}$, Surpam et al. (2019) ${ }^{[15]}$ and Shukla et al. (2019) ${ }^{[14]}$.

The angle of repose of sorghum and maize were $40.50^{\circ}$, and $45.52^{\circ}$ respectively. The angle of repose of the grain would be more appropriate in determining the inclination of the seed delivering chute and seed separators. The angles of repose of sorghum and maize are given in table 3 . The average values of static coefficient of friction against steel and galvanized iron sheet and wooden plate for sorghum and maize were 0.21 and $0.51,0.31$ and $0.52,0.26$ and 0.41 respectively present in table 3 .

Table 1: Physical properties of sorghum

\begin{tabular}{|c|c|c|c|c|c|c|}
\hline Property & No. of observation & Minimum & Maximum & Mean & SD & CV \\
\hline M.C. (\%) & 10 & 11.69 & 11.85 & 11.75 & 0.06 & 0.53 \\
\hline Length (mm) & 10 & 5.46 & 5.60 & 5.56 & 0.04 & 0.72 \\
\hline Width $(\mathrm{mm})$ & 10 & 5.00 & 5.12 & 5.05 & 0.04 & 0.83 \\
\hline Thickness $(\mathrm{mm})$ & 10 & 3.46 & 3.60 & 3.56 & 0.05 & 1.43 \\
\hline Geometric mean Diameter $(\mathrm{mm})$ & 10 & 4.56 & 4.68 & 4.64 & 0.03 & 0.74 \\
\hline Arithmetic mean diameter $(\mathrm{mm})$ & 10 & 4.65 & 4.76 & 4.72 & 0.03 & 0.68 \\
\hline Sphericity & 10 & 0.82 & 0.84 & 0.83 & 0.01 & 0.74 \\
\hline True density $\left(\left(\mathrm{kg} \mathrm{m}^{-3}\right)\right.$ & 10 & 1439.25 & 1463.05 & 1455.44 & 8.54 & 0.59 \\
\hline Bulk density $\left(\mathrm{kg} \mathrm{m}^{-3}\right)$ & 10 & 808.32 & 820.32 & 814.62 & 4.69 & 0.58 \\
\hline Porocity $(\%)$ & 10 & 0.44 & 0.44 & 0.44 & 0.00 & 0.36 \\
\hline
\end{tabular}

Table 2: Physical properties of maize

\begin{tabular}{|c|c|c|c|c|c|c|}
\hline Property & No. of observation & Minimum & Maximum & Mean & SD & CV \\
\hline M.C. (\%) & 10 & 12.49 & 12.55 & 12.52 & 0.02 & 0.18 \\
\hline Length (mm) & 10 & 10.11 & 10.21 & 10.15 & 0.04 & 0.37 \\
\hline Width (mm) & 10 & 8.01 & 8.19 & 8.11 & 0.06 & 0.75 \\
\hline Thickness (mm) & 10 & 4.11 & 4.28 & 4.22 & 0.05 & 1.17 \\
\hline Geometric mean Diameter (mm) & 10 & 6.94 & 7.08 & 7.03 & 0.05 & 0.68 \\
\hline Arithmetic mean diameter (mm) & 10 & 7.43 & 7.54 & 7.49 & 0.04 & 0.55 \\
\hline Sphericity & 10 & 0.68 & 0.69 & 0.69 & 0.00 & 0.62 \\
\hline True density (kg m$\left.{ }^{-3}\right)$ & 10 & 720.87 & 729.87 & 726.34 & 3.28 & 0.45 \\
\hline Bulk density $\left(\mathrm{kg} \mathrm{m}^{-3}\right)$ & 10 & 1202.30 & 1219.79 & 1211.79 & 7.34 & 0.61 \\
\hline Porocity (\%) & 10 & 0.39 & 0.41 & 0.40 & 0.01 & 1.36 \\
\hline
\end{tabular}

Table 3: Frictional properties of sorghum and maize

\begin{tabular}{|c|c|c|c|c|c|c|c|c|}
\hline \multirow{2}{*}{ Property } & \multicolumn{1}{|c|}{ Angle of repose } & \multicolumn{6}{|c|}{ Static coefficient } \\
\cline { 2 - 9 } & \multirow{2}{*}{ Sorghum } & \multirow{2}{*}{ Maize } & \multicolumn{3}{|c|}{ Sorghum } & \multicolumn{3}{|c|}{ Maize } \\
\cline { 4 - 9 } No. of observation & & & Steel & GI & Wooden & Steel & GI & Wooden \\
\cline { 4 - 9 } & 10 & 10 & 10 & 10 & 10 & 10 & 10 & 10 \\
\hline Minimum & 40.30 & 45.10 & 0.21 & 0.31 & 0.25 & 0.50 & 0.50 & 0.40 \\
\hline Maximum & 40.93 & 46.00 & 0.22 & 0.32 & 0.26 & 0.52 & 0.52 & 0.43 \\
\hline Mean & 40.51 & 45.52 & 0.22 & 0.31 & 0.26 & 0.51 & 0.52 & 0.41 \\
\hline SD & 0.19 & 0.30 & 0.00 & 0.00 & 0.00 & 0.01 & 0.01 & 0.01 \\
\hline CV & 0.48 & 0.66 & 1.44 & 1.02 & 1.22 & 1.44 & 1.31 & 1.91 \\
\hline
\end{tabular}




\section{Conclusions}

To design equipment and facilities for handling, processing, drying and storing grains, there physical properties must be known. The physical properties viz. length, width, thickness, geometric mean diameter, sphericity, bulk density, true density, porosity, moisture content, angle of repose and surface area of sorghum were $5.56 \mathrm{~mm}, 5.05 \mathrm{~mm}, 3.56 \mathrm{~mm}$, $4.64 \mathrm{~mm}, 0.83,814.62 \mathrm{~kg} / \mathrm{m}^{3}, 1455.44 \mathrm{~kg} / \mathrm{m}^{3}, 0.44 \%, 11.75 \%$ d.b., $40.50^{\circ}, 67.93 \mathrm{~mm}^{2}$ respectively. The length, width, thickness, geometric mean diameter, sphericity, bulk density, true density, porosity, moisture content, angle of repose and surface area of maize were $10.15 \mathrm{~mm}, 8.11 \mathrm{~mm}, 4.22 \mathrm{~mm}$, $7.03 \mathrm{~mm}, 7.03 \mathrm{~mm}, 0.69,726.34 \mathrm{~kg} / \mathrm{m}^{3}, 1211.79 \mathrm{~kg} / \mathrm{m}^{3}, 0.40 \%$, $12.52 \%$ d.b., $45.52^{\circ}, 155.08 \mathrm{~mm}^{2}$. The average values of static coefficient of friction against steel and galvanized iron sheet and wooden plate for sorghum and maize were 0.21 and $0.51,0.31$ and $0.52,0.26$ and 0.41 respectively. This properties determined the dimensions of machine parts such as hopper, metering unit, shelling drum, concave and separating sieves and the angles of inclination and clearance of this parts in relation to one another. The choice of construction materials for different machine in view of the desired throughout Capacity also depends on a working knowledge of these properties. To avoid breaking and crushing the seeds during the shelling and milling operation and thereby reducing the quality and causing seed losses, there is need to characterize the grains in term of these properties before designing the machine equipment for handling and processing of the sorghum and maize.

\section{References}

1. Anglani C. Sorghum for human food - A review Plant Foods for Human Nutrition. 1998; 52:85-95.

2. Davies RM. Some Physical Properties of Groundnut Grains. Research Journal of Applied Sciences, Engineering and Technology. 2009; 1(2):10-13

3. Edward A Baryeh. Physical properties of bambara groundnut. Journal of Food Engineering Research. 2001; 47:321-326.

4. Gupta RK, Das SK. Physical properties of groundnut. Journal of Agricultural Engineering Research. 1997; 66:1-8.

5. Ganjeer I, Patel S, Nambi VE. Development of rapid and novel method for detection of insect infestation during storage of wheat and maize using dielectric and thermal properties. International Journal Curr. Microbiol. App. Sci, 2019; 9:85-94.

6. Jain R, Bal S. Properties of pearl millet. Journal of Agricultural Engineering Research. 1997; 66(2):85-

7. Maduako JN, Hamman M. Physical properties of three groundnut varieties. Nigerian Journal of Technology. 2004; $24: 12$.

8. Mccabe WL, Smith JC, Harriott P. Unit operations of chemical engineering. New York: McGraw-Hill.Olajide, J.O. and Igbeka, J.C., 2003. Physical properties of groundnut kernels. Journal of Food Engineering Research. 1986; 58:201-204.

9. Mohsenin NN. Physical Properties of Plant and Animal Materials, 2nd edition. Gordon and Breach Science Publishers, New York, Sahay, K.M. and Singh, K.K.,1999. Unit operation of Agricultural processing. Vikas publication House, New Delhi, 1986.

10. Olajide JO, Igbeka JC. Some physical properties of groundnut kernels. Journal of Food Engineering. 2003; 58(2):201-204.
11. Sangamithra A, Swamy GJ, Sorna Prema R, Nandini K, Kannan $\mathrm{K}$, Sasikala $\mathrm{S}$ et al, Moisture dependent physical properties of maize kernels. IFRJ. 2016; 23(1):109-115

12. Sebaka A. Physical properties of bambara groundnut from botswana. Journal of Food Engineering Research. 2008; 89:93-98.

13. Sahay KM, Singh KK. Unit Operations of Agricultural Processing, Vikas Publishing, 1999.

14. Shukla S, Makwana A, Gupta RA. Determination of Some Engineering Properties of Groundnut Pod (Gg-20 Variety). Internatonal Journal Curr. Microbiol. App. Sci. 2019; 8(2):3025-3030.

15. Surpam TB, Pardeshi IL, Rokade HN. Engineering properties of sorghum International Journal of Chemical Studies. 2019; 7(5):108-110. 